\title{
PUTTING THE 'EQUAL' INTO 'EDUCATIONAL OPPORTUNITY': THE POLITICS OF EDUCATION IN NEW ZEALAND DISTRICT HIGH SCHOOLS, 1869-1969
}

HOWARD LEE ${ }^{1}$ AND GREGORY LEE ${ }^{2}$

1. Department of Education, University of Otago

2. Department of Educational Studies, University of Waikato

ABSTRACT The attempt and subsequent failure by the Department of Education, its Directors and successive Ministers of Education to introduce and popularise agricultural subjects and courses in New Zealand rural high schools, following the passage of the Education Act of 1877, illustrates the tension that existed - and still exists - in reconciling the conflicting official expectation that these schools should provide vocational courses leading to employment in the local economy with the community's demand for access to academic courses and examination credentials that offered geographical and social mobility to ambitious youth.

Instead of reaching a consensus, the central authorities quickly became deadlocked over the type and extent of educational reform required. On the one hand, if rural subjects were made examinable, they would quickly become institutionalised as knowledge to be gained only from textbook study. On the other hand, if these subjects were not examined, there was every likelihood that the more academically able pupils would avoid them, the end result being that rural subjects (and courses) would become identified as the preserve of a non-selective, low-status, low achieving group. The issue was further complicated by the reality that the traditional (academic) subjects had superior status. In practice, then, it was preparation for examinations which came to dominate the work of the rural high schools.

\section{THE EARLY YEARS: 1856-1876}

Under the Constitution Act of 1852, New Zealand adopted a federal system of government whereby the colony was divided into six provinces (Auckland, New Plymouth, Wellington, Nelson, Canterbury, and Otago), each with its own elected provincial council (i.e. regional government) enjoying wide-ranging powers. The provincial councils each assumed responsibility for education, but because they differed widely in their philosophies, resources, practices, resources and the value of their various educational endowments, educational provision throughout the colony became extremely uneven. Disparities between the South and North Islands widened owing to the rising economic fortunes of the former. Ravaged by war and lacking the South Island's substantial financial reserves and church endowments (to the extent that the Auckland province faced virtual bankruptcy 
over the years 1866-1869), the North Island provincial governments experienced acute financial difficulties, whereas the South Island economy flourished as a result of the discovery of gold and the increasing revenue derived from the sale of vast quantities of treeless, fertile land. ${ }^{1}$

From the outset, the education systems established in each of the six provinces reflected, to a greater or lesser extent, existing educational practices in England and/or Scotland during the first half of the nineteenth century. In the absence of national provision (and funding) for schooling, a number of provinces opened primary schools during the early 1850 s, often paid for by way of public subscription and school fees.

The educational achievements of the South Island provinces were not inconsiderable. The Otago province, for example, began with five primary schools established under the first Education Ordinance in 1856.

By the close of the provincial period (1876), the number of schools had grown to 173 . In the same period, the number of pupils in average daily attendance increased from 236 to 11210 per year, and the number of teachers employed in Otago schools climbed from seven to 329.2 In relation to the other provinces Otago teachers were well-paid, and the province was able to attract experienced teachers from overseas. Being a Scottish Presbyterian settlement, Otago recruited many of its teachers who had been trained in, and certificated by, Scottish Normal Schools. ${ }^{3}$

In keeping with the traditional Scottish zeal for education, some local communities approached the Otago Education Board with a view to obtaining the board's permission (and funding) to establish schools modelled on the Scottish parish system, wherein schools were built in each parish to provide instruction in almost any secondary school subject on payment of a very modest fee. 4 The first of these schools opened in Tokomairiro (Milton) in April 1856. After a somewhat unpromising start - the school closed briefly in 1861 owing to a lack of pupils ${ }^{5}$ Tokomairiro District High School's future became more certain in 1869 when the Grammar Schools Ordinance was passed which reconstituted the school, along with three others (Lawrence, Port Chalmers, and Oamaru), as a grammar school.

As academic institutions designed to provide a very small number of ambitious scholars with the opportunity to undertake secondary (grammar) school studies, between them the four Otago schools offered courses in English (including reading, recitation, and grammar), Latin, Greek, French, Euclidian geometry, Algebra, British history, and World Geography. ${ }^{6}$ Interestingly, in the very early years of the Otago grammar schools, the pupils were examined orally on these subjects by 'prominent men in the community'. 7 After 1877, however, these examinations were conducted by the Otago Education Board's own inspectorate.

\section{THE EDUCATION ACT, 1877}

By 1877, the district high schools in Otago had won popular acclaim by providing the means by which academically able primary school youth could gain access to low cost post-primary schooling. 8 Teachers such as John Stenhouse, Rector of Lawrence District High School, knew only too well what their local communities expected of them, and they responded accordingly. Stenhouse had realised that 
in depopulating towns with stagnant economies, such as the gold mining town of Lawrence, there would be few employment opportunities, and consequently he devoted himself to preparing rural youth for future government employment, and office and commercial work in the towns and cities.9 Upward social and vocational mobility for youth attending the rural high schools thus emerged as the highest priority in the minds of many rural residents; priorities which envisaged numerous advantages from residing in urban centres. As Thom observed, "the dominating idea was that of getting out [of rural areas] to get on."10 Clearly, given that the school authorities could not afford to ignore the demands of their local communities, formal legislative provision was deemed necessary to preserve the all important equality of curricular offerings between town and country high schools. 11

With the passage of the Education Act in 1877, not only did the government assume full responsibility for primary education but also it set the district high schools on the road to becoming credential-preparing institutions. The 1877 Act allowed each of the regional education boards, on receiving an application in writing from a school committee and with prior approval from the Minister of Education, to convert any public primary school into a district high school.12 Thus Lawrence, Oamaru, Post Chalmers and Tokomairiro in Otago, having been renamed grammar schools in 1869 , became officially recognised under the Act as being district high schools proper. ${ }^{13}$ In addition to granting statutory recognition to district high schools nationally, the 1877 Act also prescribed an academic course of instruction for pupils studying in the secondary departments ('tops') of these institutions. The statute set out a curriculum which was already familiar to the district high school teachers and rural residents of Otago. It read:

[Pupils were to study] all the branches of a liberal education comprising Latin and Greek classics, French and other modern languages, and such other branches of science as the advancement of the colony and the increase in population may from time to time require. ${ }^{14}$

If the claim that the founding purpose of the district high schools was to 'equalise educational opportunity between town and country; to facilitate the rise of credentialled talent'15 is indeed correct, then one would expect to find a high degree of similarity between the curricular offerings of these schools and the town secondary schools. In point of fact, the historical record strongly supports this hypothesis: the Education Reserves Act, 1877, allowed endowed secondary schools to provide instruction in the 'usual branches of a liberal education consisting of the English language and literature, Latin and Greek classics, French and other modern languages, Mathematics, physics and other branches of science'.16 Thus, the district high schools could justifiably state that they offered genuine equality of educational opportunity by modelling their curriculum on traditional academic lines so as to provide schools with the opportunity to gain precisely the same examination qualifications as offered by the exclusive, feecharging secondary schools in urban areas. It was a situation which few district high school teachers were prepared to challenge. ${ }^{17}$ 


\section{THE DISTRICT HIGH SCHOOL EXPERIMENT, 1877-1899}

The growth in the number of district high schools established after the passage of the 1877 Act was disappointingly slow. Few education boards, it seems, were willing to experiment with this new institution. Over the period 1877-1899, the number of district high schools established increased from five (all in Otago) to 14 (five in Otago, seven in other South Island areas, and two in the North Island) with a combined enrolment of 313 pupils in the secondary departments. ${ }^{18}$ The fate of the district high schools appeared to hang in the balance owing to three factors that, taken together, were not conducive to any developments in postprimary education provision.

In the first place, because the district high schools were funded out of ordinary capitation and the cost per pupil was higher owing to the better salaries paid to teachers in the secondary departments, the schools could grow only at the expense of their primary school base. In Wanganui's case, the education board soon discovered that the cost per pupil in their district high schools was more than twice that for a pupil in their primary schools. ${ }^{19}$ Given the urgent need to service increases in primary school enrolments at this time, most of the district high schools' secondary departments were inadequately staffed and resourced. Secondly, the situation was further complicated by the onset of a major economic depression which lasted throughout the 1880 s and 1890s, and which resulted in decreased educational expenditure. ${ }^{20}$ In light of these financial constraints, it was predictable that post-primary education would assume lesser importance for the remainder of the nineteenth century. The future of the district high schools, at least for the time being, remained uncertain. ${ }^{21}$ Thirdly, the historical record clearly demonstrates that the whole post-primary sector itself was deeply divided over the respective roles that the district high and secondary schools were to occupy. For their part, the secondary school authorities regarded the district high schools as nothing more than interlopers; as institutions which competed for a scarce commodity in an exclusive segment of the school market.22

Given the competitive nature of the post-primary education marketplace, no relief was forthcoming from the considerable curriculum overlap which existed between the district high and urban secondary schools; an overlap that was the direct result of ensuring that ambitious post-primary school youth had access to public school examinations. ${ }^{23}$ Rural communities were keen to preserve this overlap because they saw it as affording some guarantee that the district high school authorities would be able to offer genuine equality of educational opportunity alongside urban secondary schools. As the Southland Education Institute observed in 1910, 'the effect of an examination common to a group of schools was to lead to their programmes of work being similar'. ${ }^{24}$ From the public perspective, examinations came to be synonymous with high quality academic instruction, efficient and effective teaching, and enhanced social and vocational mobility. District high school teachers, in almost every instance, were understandably unwilling to criticise and contradict the demands of their conservative communities. ${ }^{25}$ 


\section{THE HOGBEN YEARS: 1899-1915}

The decision by the majority of district high school authorities to respond to the academic demands of their local communities was being sharply criticised in some quarters by the end of the nineteenth century. These critics argued that the time was now ripe to introduce a practical, agricultural bias into the district high school curricula in place of the traditional academic offerings. Placing more emphasis on agricultural instruction was considered appropriate because it was assumed (erroneously) that male pupils would most likely take up farming work upon leaving school.26 This view was endorsed by the Minister of Education and Premier, Sir Robert Stout, and many school inspectors who declared the district high school curriculum to be overly academic and lacking a special bias towards agriculture. ${ }^{27}$

The newly-appointed Inspector-General of Schools, George Hogben, agreed. Hogben questioned the need for the district high schools to teach the traditional secondary school curriculum and for them to imitate fully-staffed secondary schools by modelling their programmes on the assumption that the majority of district high school pupils intended to go on to the university. A pupil's general education, he declared, did not always have to be grounded in academic instruction; rather, it could be obtained through practical, manual studies. ${ }^{28}$ Somewhat defiantly, Hogben attempted to persuade rural communities to accept that the discernible market trend whereby employers valued most highly as potential employees those pupils who had pursued academic courses was both educationally unsound and economically undesirable. In short, the InspectorGeneral sought to alter the market perception of what counted as being the most suitable kind of rural post-primary schooling within a rural context.

Hogben's task was further complicated by the introduction of the Seddon (Liberal) government's 'free place' system. In January 1901, the education boards were offered a grant of $£ 30$ per annum for each district high school having 12 or more pupils taking a full secondary course, along with an annual capitation payment of $£ 2$ per pupil. ${ }^{29}$ It was further provided that where fees were not charged, the government would contribute an additional $£ 4$ per pupil. ${ }^{30}$ Thus, the total amount payable to the boards for each district high school pupil was $£ 6$ plus the standard statutory capitation allowance of $£ 3.15 \mathrm{~s} .{ }^{31}$ These allowances were paid subject to four conditions being met: first, capitation would be paid only for pupils who had passed the Standard 6 Proficiency Examination; 32 second, pupils were to be taught in separate classes by properly qualified teachers; ${ }^{33}$ third, the allowances were to be paid as salaries to the secondary school teachers or as additions to the salaries of those teachers in charge of the secondary classes; ${ }^{34}$ and, finally, that all pupils were to include English and arithmetic in their courses, and at least three other subjects chosen from a list comprising Latin, French, mathematics (euclid, algebra, trigonometry), elementary mechanics, physics, chemistry, botany, mechanical drawing, book-keeping, shorthand, agricultural chemistry, and physiology.35

Having seriously underestimated the public enthusiasm for the Liberal government's free place system - the arrangement was extended to include the secondary schools in December 1902 - Hogben was unable to predict the extent to which the free place legislation would further entrench academic instruction in 
the district high schools. With a broader curriculum in place from 1901, Hogben confidently expected the majority of district high school pupils to opt for the manual-technical and agricultural science subjects now available. ${ }^{36}$ But this was not to be. Deeply disappointed with the conservative response from the district high school authorities, Hogben issued a 'note of warning' in his annual report to the House of Representatives in 1901. He wrote:

There is too much tendency at present... to give the [secondary] pupils a little Latin or French and a little elementary algebra or Euclid, and to avoid science and commercial and manual training. The aim in view in establishing district high schools will probably be gained if these schools give the pupils a good taste for secondary English literature, a thorough training in ordinary English composition and in arithmetic and mensuration, and such knowledge of history and geography as will enable them to understand better their duties as Citizens of the Empire, adding thereto a course in elementary science - and a suitable course of manual work or of commercial work where local conditions demand it... There is no reason why any of our district high schools... should take as their model the lower forms of an old English grammar school. 37

This theme was to dominate Hogben's tenure of office as Inspector-General of Schools (1899-1915), and he retired in the full knowledge that few of the district high schools had viewed his proposals seriously or even greeted them warmly. ${ }^{38}$

Hogben, along with several prominent school inspectors, openly admitted to being perplexed by the rural schools' resistance to reform their curriculum along the lines that he had envisaged, and he remained unswerving in his belief that a large, attractive employment market existed for rural school leavers trained along agricultural and pastoral lines. ${ }^{39}$ It was a message that he was to repeat to a Hawke's Bay branch meeting of the Farmers' Union in 1904.

Hogben began his address with a concerted attack on the academic nature of the district high school curriculum. 'One of the most urgent needs of the colony', he argued, was 'properly organised instruction in the principles of agriculture.'40 Equating New Zealand's future economic prosperity with a vigorous rural education programme, Hogben continued:

Agricultural and rural pursuits engaged the efforts . . of far more people than any other single trade, business or manufacture ... . [and] of more individuals than all other productive occupations put together. ${ }^{41}$

Having extolled the virtues of agricultural education, Hogben then expressed great surprise that the district high schools were keen to provide instruction in subjects such as typewriting and shorthand in preference to agriculture, dairy work, and cottage gardening. 42 But he stopped short of advocating compulsory agricultural education in country high schools, arguing instead that the Department of Education, by its general regulations and the special capitation grants it offered to education boards, provided encouragement to schools to introduce 'such instruction as is most suited to the district. ${ }^{43}$ In addition, Hogben 
suggested that rural communities should 'use their influence' to move the local educational authorities and local public opinion in the direction of providing rural education programmes in their schools. ${ }^{44}$ Clearly, persuasion was felt to be infinitely preferable to legislative compulsion.

In condemning the academic curriculum of the district high schools and the fact that they offered instruction in commercial subjects, Hogben misread the intense market demand for courses of study (and examination qualifications) that provided rural youth with enhanced employment opportunities. But he was not alone. At the same time as he was advancing the case for agricultural education in rural schools, Frank Tate, the highly respected Director of Education for Victoria, Australia, was compiling his own special report on the New Zealand education system. ${ }^{45}$ Tate found himself to be in complete agreement with Hogben. The New Zealand district high schools, in Tate's opinion, 'devoted too much attention to what are usually called "high school" subjects'. 46 Like his New Zealand counterpart, Tate expressed his fervent hope that these schools would assume full responsibility for agricultural training and education. $\mathbf{~} \mathbf{7}^{\mathbf{7}}$

Clearly, Hogben and Tate had not fully understood the implications of the rural-urban drift on school-based agricultural education programmes. Stout, by contrast, had been alert to this reality as early as 1886 when designing the Junior Civil Service Examination - a dual-purpose qualification used to select candidates for entry to civil service cadetships and to certificate primary school teachers. ${ }^{48}$ In retrospect, it can be seen that any attempt on the part of officialdom to upset the opportunity for social and geographical mobility was likely to encounter extreme hostility. Shramka's research on Petone High School provides strong support for this claim. ${ }^{49}$ In 1908, the school offered two courses - a 'general' examinationoriented course (English, Latin, French, Arithmetic, Algebra, Geometry, History, and Chemistry) and a 'commercial' course (Book-keeping, Shorthand, Freehand Drawing, and Brushwork).50 An attempt three years later to offer an alternative programme of technical and rural instruction was strongly resisted by many members of the community who felt that these courses would interfere with preparation for the Junior Civil Service Examination. 51 The local press agreed; the editor of the Hutt and Petone Chronicle was moved to write that such courses were merely 'fads'. 52 He observed that because Petone was predominantly a working-class community, 'pupils desiring government positions must be able to sit for competitive examinations'.53 Finally, after much debate, the Wellington Education Board intervened. The solution, arrived at included retaining the general (examination-based) and commercial courses, and to offer an additional rural course which included elementary agriculture and botany. The remaining subjects in the rural course were those already taught in the commercial course. ${ }^{54}$ The rural course, however, was neither popular nor successful, the general course continuing to attract the greatest proportion of pupils. The former course was finally abandoned in 1917.55

What the Petone example clearly demonstrates is that a well-known school credential, in the form of the Junior Civil Service Examination, allowed youth an opportunity to compete in the employment market. It is not at all surprising, therefore, that the Department's attempts to reform the school curriculum (for example, to introduce rural studies into rural schools) were destined to founder. 
In short, the majority of pupils and parents did not want the curriculum to be broadened because, as it stood, it was doing precisely what they wanted it to do.

Faced with the reality of pupils desiring the same examination qualifications that were obtainable from the town secondary schools, the rural high school teachers were happy to oblige by preparing their pupils for such qualifications. Thus the district high schools had joined in the credential race. The Westland Inspector of Schools, A.J. Morton, reported that the great majority of primary school children in his district who went on to the local district high school did so with the express intention of securing passes in the Junior Civil Service Examination in order to gain appointments in the civil service, in offices, or as pupil-teachers. ${ }^{56}$ Another inspector, Henry Hill of Hawke's Bay, in his report of 1905, noted that the range of subjects available in the Junior Civil Service Examination was wide enough to be 'easily adaptable to the varying wants of each district'.57 In Hill's opinion, the examination was an ideal objective to which all rural high school pupils should aspire. He wrote:

It appears to me that the time has arrived for all district high school pupils to be tested through the channel of the public examination... The Junior Civil Service and Matriculation [Examinations] should be the objective of every pupil. These examinations would supply a suitable leaving certificate. $\mathbf{5 8}$

Given such official encouragement, it is therefore not surprising that the district high schools attached little importance to the idea that they should become centres of education for pupils who would remain in the rural community. They preferred, instead, to meet the demand for courses leading to recognised public examinations. That was what parents and pupils wanted, and that was what the schools sought to provide.

Seemingly oblivious to the reality that rural residents regarded agricultural instruction as an imposition upon the academic work of the district high schools, Hogben clung to the view that rural youth should follow a practical curriculum with a distinct agricultural bias. In an address to a Conference of Inspectors and Training College Principals in 1907, Hogben urged that a 'good practical and theory course of agricultural instruction should be taken in every district high school in New Zealand and also in many of the secondary schools'.59 Visits to a number of district high schools had confirmed his opinion that the academic courses on offer in these schools were inappropriate since they bore little, if any, relationship to the life of the district.60 With a strong sense of purpose, Hogben gave legislative effect to his convictions. In 1909, he offered a special capitation grant of $£ 5.10$ s annually to each education board for each pupil in their district high schools who took an approved agricultural education course. ${ }^{61}$

Hogben's initiative met with some success. By 1912, rural courses had been established in the Temuka, Waimate, Tokomairiro, Lawrence, Mosgiel, Tapanui, Palmerston South and Alexandra District High Schools in Otago, and in a number of secondary and technical high schools throughout the South Island.62 As a general rule, however, post-primary schools in the South Island were slower to introduce rural courses than those in the North Island.63 Nevertheless, Hogben's vision appeared to be materialising. 
But all was not well. Considerable difficulties were experienced in obtaining staff capable of teaching agricultural subjects at the post-primary school level.64 Another obstacle, as we have seen, was the fact that most pupils who undertook rural subjects or a rural course also were preparing for national examination qualifications - most notably, Junior Civil Service and Matriculation. ${ }^{65}$ Like Hogben, the Minister of Education, George Fowlds, was convinced that school examinations exercised too great an influence upon the district high school curricula. 'Everything', he reported, 'is subordinated to securing high marks in competitive examinations'.66 Fowlds also assumed that community preferences, even long-established ones, could easily be modified by Ministerial decree. ${ }^{67}$ But as he and his successors were soon to discover, market forces continued to exert a powerful grip upon the public perceptions of the knowledge of most worth.

Hogben's attempts to 'bring about a more intimate relation between the courses of instruction at district high schools and rural pursuits' 68 attracted the wrath of the more market-conscious education boards and their inspectors who saw it as a direct threat to the credentialling function of rural high schools. The Otago Education Board's subcommittee on district high schools, established in 1908, told Hogben and Fowlds that the dual (i.e. academic-practical education) function of district high schools should be left intact, thereby protecting the 'interests of the main body of pupils as well as the select few'.69 An even more trenchant criticism of Hogben's proposal to reorientate the district high schools offerings came from Peter Goyen, Chief Inspector of Primary Schools in Otago. In a lengthy address to the Otago Education Board in July 1909, Goyen declared that Hogben's plan to convince rural residents that their support for academic instruction and, more recently, commercial studies was in fact unacceptable because 'it [would] not provide for what parents regard as the needs of their children'. ${ }^{70}$ In a carefully worded statement to his board, Goyen observed that:

At present the chief aim [of district high schools] is to prepare their pupils for public examinations. It is right that, as far as practicable, country children should share with town children in the provision made by the state for education for public office and professional careers, and no scheme of work should be imposed upon rural schools that would deprive or tend to deprive country children of their share in this provision. ${ }^{71}$

Hogben's rural curriculum proposals, Goyen concluded, lacked solid market support simply because they were inimical to the 75 per cent of district high school pupils who were studying for either the Junior Civil Service or University of New Zealand Matriculation Examinations. ${ }^{72}$

The debates regarding the district high school curricula highlighted the very real difficulties that were encountered when an institution, by virtue of its geographical location, was expected to serve broadly academic and practical purposes. It was this dual purpose that led education officials to argue at length about which 'side', academic or practical/applied, ought to be given priority. For the time being, Hogben and his Minister determined that the best course of action was to acknowledge 'the difficult position' occupied by the district high schools by virtue of their 'having to serve a double purpose'. ${ }^{73}$ That said, however, it was 
clear that Hogben favoured curriculum differentiation whereby the vocational aspirations of pupils, their intellectual abilities, and their intended duration of stay at a post-primary school, were to determine their particular course of study. ${ }^{74}$ According to this principle, pupils attending a rural high school whose length of stay was short were expected to follow a practical curriculum with a distinct practical bias - i.e. agriculture and dairy science for boys, domestic science for girls - while longer-stay pupils would enter the academic, examination-directed course. 65

Hogben and Fowlds' understanding of (and emphasis on) 'educational efficiency' led them to claim that 'some sort of distinct natural sifting of pupils' ought to occur; that is, pupils should be permitted to embark upon the Matriculation course only if they fully intended to proceed to University study. ${ }^{76}$ However, neither the Department of Education's Free Place Regulations nor the University of New Zealand's Matriculation Examination requirements imposed such a limitation upon pupils. ${ }^{77}$ Moreover, since the post-primary schools did not have a compulsory market - rather, it was a voluntary market within which high schools competed for pupils who were not compelled by law to attend these schools - they were obliged to respect the wishes of those pupils who did choose to attend. ${ }^{78}$ Frustrating as it was to them, Hogben and Fowlds were powerless to intervene in a market that had identified examinations as being the raison d'être of a post-primary school education. The Inspector-General, the Minister of Education, and the Department knew that many high school principals were unapologetic that the demands placed on them by their pupils in fact governed schools' practices such that the position of ambitious, credential-conscious youth in the high schools had to be safeguarded.79 Without access to the all-important examinations, it was likely that the public would have viewed non-academic courses as being unattractive options.

Nevertheless, this realisation did not deter Hogben from continuing to remind the post-primary school teachers of their 'special obligation' to educate their non-academic pupils under the existing Free Place Regulations. ${ }^{80}$ In his opening address to the Education (Cohen) Commission in 1912, Hogben argued that schools ought to offer courses that had 'some bearing on the future lives of the pupils' ${ }^{81}$ The New Zealand public's 'craze for examinations', he observed, had effectively prevented an agricultural bias from being incorporated into the district high school curriculum. 82

The inspectorate sided with Hogben. George Braik, Chief Inspector for the Wanganui Education Board, and Edward Mulgan, Chief Inspector for the Auckland Board, both informed the Cohen Commission that the rural course, as it operated in the district high schools, handicapped those intent on preparing for the Junior Civil Service and Matriculation Examinations. ${ }^{83}$ The Wellington Inspector, Frederick Bakewell, noted that attempts to establish full rural courses in high schools in his district from 1910 had been disastrous. Despite his censuring these schools for allowing examinations to override 'the benefits of a vocational training in the agricultural and pastoral occupations', the rural course still met with 'strong opposition from local communities' simply because it was seen to jeopardise the interests of examination candidates. ${ }^{84}$ The reason for the rural course being popularly perceived as being the 'poor relation' to the examination course, Bakewell reasoned, lay in its inability to provide a foothold 
on the social mobility ladder. ${ }^{85}$ Leonard de Berry, Headmaster of Hokitika District High School, put the matter succinctly when he observed that the rural course was the victim of the law of supply and demand. He concluded:

In our district high school the trouble is there is no demand at all for any special local training, because practically every boy and girl who goes to the high school there goes with the object of passing Junior Civil Service and Matriculation and getting off the [West] Coast as soon as possible... The demand down there is for the teacher to prepare the pupil to get off the Coast.86

Preparation for examinations, de Berry reported, 'discounted education for anything else'.87

Arguments such as these were not lost on other educationists who appeared before the Cohen Commission. Noting the sustained high level of public demand for school credentials, the Principal of Wanganui Collegiate, the Rev. Julian Dove, remarked that although public opinion in this regard tended to be basically utilitarian, 'it knows what a school is doing, and it knows what it wants that school to do'.88 His comment was markedly at odds with that of Mr McLeod, President of the South Canterbury branch of the New Zealand Educational Institute (NZEI) who, in the face of strong evidence to the contrary, was confident in 1912 that 'people will come to see that it is just as respectable an occupation to be driving a plough as to be driving a quill'.89 Ignoring the wealth of evidence that the terminal, agriculturally-oriented course was powerless to compete with the portability, marketability, and status of recognised public examinations, the Commissioners concluded that,

One of the main, if not the chief, defects of the present system of education is its tendency to make the public examinations the objective, the result being that the ranks of clerks (in the case of men) and of typists (in the case of young women) are unduly extended. The growth of the cities at the expense of the rural and country districts, as disclosed by the latest [1911] Census, is disquieting. If the suggested modifications of the syllabus result in a bias being given to the primal industries of the Dominion...and to the increased productiveness of the soil, the Commission is convinced that the material prosperity of the people of the Dominion will be greatly enhanced. ${ }^{90}$

Although the Cohen Commissioners recommended giving agricultural subjects higher marks in the Junior Civil Service and Matriculation Examinations in order to give a stronger bias to the 'primal industries of the Dominion' and to enhance New Zealand's 'material prosperity', the Commissioners were at a loss to suggest any alternative arrangement which would stem the public's insatiable demand for academic examination qualifications. ${ }^{91}$ Predictably, the longestablished academic subjects continued to dominate the curricular offerings of most district high schools to such an extent that only ten per cent of all senior free place holders (Forms 5 and 6) were undertaking the full agricultural course as late as 1925.92 The Cohen Commissioners, it seems, had been blind to the fundamental reality that the 'market' and the examination system had simply 
subverted the best attempts by educational planners to provide an education programme designed with perceived local needs in mind. The public, therefore, were not about to vote for an easing of the examination treadmill.

Support for the view that the agricultural course would provide 'as good an education as the professional (academic) course' was minimal.93 Four leading school principals - James Tibbs, Rector of Auckland Grammar School; John Caughley, Headmaster of West Christchurch District High School; Charles Bevan-Brown, Rector of Christchurch Boys' High School; and T.D. Pearce, Rector of Southland Boys' High School, upheld the conservative view that the only education worth striving for was one that offered high-status academic knowledge leading directly to public examinations.94 The difficulty of introducing into curriculum regulations subjects that did not alienate academic pupils and which attempted to provide a 'realistic education' for the great majority of post-primary pupils who remained at school for less than two years continually troubled the Department, successive Directors and Ministers of Education, for the remainder of the period under review. ${ }^{95}$

\section{THE CHANGING POST-PRIMARY SCENE: 1915-1929}

Shortly after Hogben retired as Inspector-General of Schools in 1915, Josiah Hanan was appointed Minister of Education. Arguing that there was a pressing need to 'review existing (educational) conditions in the light of national requirements', Hanan immediately set out to make the high school curriculum 'a closer reflection of the democratic ideals of the country than it used to be'.96 In essence, he believed that the post-primary schools had to 'enter more fully and widely into the life of the community'.97

With respect to the rural high schools, Hanan came out strongly on the side of agricultural instruction on the grounds that it was 'in the interests of the country'.98 The desire to popularise rural life and to elevate the status of agricultural labour and, more importantly, the increasing concern about the 'rural-urban drift', were held to be good reasons for encouraging a rural bias in these schools. ${ }^{99}$ With 'efficiency' considerations to the fore, Hanan concluded that students should be directed into one of four programmes: University preparation, General, Continuation, and Country. 100 At the same time war had become a fact of life which was to have a significant impact upon proposals for educational reform and curriculum practice. Success in those areas, Hanan believed, depended upon the Department of Education adopting a higher profile in postprimary education.101 His decision to intervene in high school affairs was defended on the ground that priority had to be given to New Zealand's post-war reconstruction. 102 In this important respect, Hanan and Hogben differed. Hogben had placed his faith in schools initiating curricular reform with support from the Department, whereas Hanan looked to educational legislation to facilitate nationwide change. ${ }^{103}$

In July 1917, revisions to the Free Place Regulations were gazetted that compelled all junior free-place (Form 3 and 4) holders attending secondary, district high and technical high schools from 1 January 1918 to receive instruction in History and Civics (for boys and girls) and Home Science (for girls); with Agricultural Science (Practical Agriculture and Dairy Science) also for boys 
attending district high schools. 104 These subjects were made compulsory, based upon their perceived educational and vocational value for third and fourth formers. ${ }^{105}$ Recognising that New Zealanders were inherently suspicious of, and resistant towards, any attempt to restrict boys' and girls' educational, social and vocational ambitions on the basis of the course of study undertaken or attendance at a particular type of post-primary school, 106 Hanan was careful to point out that a broadened high school curricula would not undermine the status of academic instruction. ${ }^{107}$ The established relationship between the school curriculum and the examination system would therefore not be jeopardised.108

Hanan's introduction of compulsory Practical Agriculture in the 1917 regulations provoked strong opposition from parents, teachers, pupils, and some education board officials. Many felt that they had had no say in the matter; that agriculture was a narrow school subject associated with low-status employment, and as such was unable to enhance the vocational mobility of country youth; and that it was both a nuisance and a low-status subject despite its featuring in Departmental and University (Matriculation) examination syllabuses. Moreover, such instruction was regarded as being 'terminal' in that it was not linked to professional vocations and therefore was not associated with the traditional syllabuses for high-status national examinations. The Wellington Inspectors summarised what they understood to be the conservative market stance:

It must be remembered that Matriculation is the preliminary step to every learned profession, and where there is a small district high school with only one secondary teacher, parents who do not intend their children to take up rural pursuits are aggrieved that the children's chances of entrance to such professions as, say, law or accountancy should be jeopardised by the requirements of compulsory training in another vocation altogether. ${ }^{109}$

Education officials were by no means united in their support for retaining academic courses in the district high schools. Differences in official thinking soon began to be voiced. The Wanganui Inspectors in 1919, for example, decreed confidently that 'the district high school has, and rightly in our opinion, little need to provide the purely literary type of instruction'.110 Whilst they agreed with their Wanganui counterparts, ${ }^{111}$ the North Canterbury Education Board Inspectors went further and argued that district high school courses should be noticeably different from those offered in the technical high and secondary schools in order to eliminate curricular overlapping which they regarded as being both inefficient and undesirable. ${ }^{112}$ Such an argument, however, ignored the reality that the curricular overlap between the three different types of post-primary schools was an inevitable consequence of school authorities working to satisfy the demands of their local communities. ${ }^{113}$ Academic and commercial courses were provided principally because there was strong employer support for them. ${ }^{114}$

Nevertheless, successive Directors and Ministers of Education doggedly insisted that agricultural education should be an indispensable feature of the district high curriculum because the nation's social, economic, and political stability depended upon educating the bulk of the adolescent population along practical lines. ${ }^{115}$ Frank Tate, Director of Education in Victoria, Australia, and 
James Parr, Minister of Education (1920-1926) under the Massey government, were two such people.

In his report on post-primary education in New Zealand in 1925, Tate claimed that conservative educational practice was deeply ingrained in rural New Zealand. He explained that:

In schools in which carefully planned courses bearing directly upon rural life and interests had been instituted, farmers preferred that their children should take Matriculation subjects rather than the special rural course.... A fashion has been set up, and the tendency is for all, both within and without the school, to conform to it. ${ }^{116}$

Tate concluded with the pertinent observation that 'social esteem vitally affects schools and school customs.' 117

Ironically, although Tate was alert to the market forces governing curricular choice in rural communities, he nonetheless emerged as a vociferous advocate for agricultural instruction. ${ }^{118}$ Similarly, Parr reasoned that because 'the prosperity of New Zealand depends largely on the development of agriculture', the Department of Education now had a duty to provide 'a sound and thorough training in agriculture'.119 Supporters of this policy confidently expected that school-based agricultural instruction would 'halt the gradual trend towards the cities and away from the farming districts'. ${ }^{120}$ Critics, for their part, were only too aware of the reluctance of some schools to depart from the traditional academic fare by teaching agriculture to unenthusiastic youth. H. Niven, Chairperson of the Southland Education Board, summarised the rural mood appropriately when he noted that 'the interests of [rural] residents cannot apparently be sufficiently aroused to enable a forward move to be made [in agricultural education]' ${ }^{121}$ The reason for this, James Wallace (Otago Education Board Chairperson) and the Wanganui Inspectors explained, was that the 'efficiency' of district high school teaching was still being judged publicly by examination results. ${ }^{122}$ Other members of the inspectorate readily acknowledged the conflict between examination requirements and the provision of a full vocational course in Agriculture.123 Although reluctant, the Director of Education, Theo Strong (19271933), eventually conceded the fate of the rural course in his evidence to the 1925 Commission on Agriculture. He concluded:

A pupil who takes the agricultural course finds it difficult to pass the public examinations, such as the Public Service Entrance and Matriculation Examinations. The examination requirements do not fit in with a full agricultural course. Consequently the boy may arrive at the end of his course and find himself without any certificate to hall mark his progress at school. Parents do not like this: they naturally desire some visible sign of the lad's progress. ${ }^{124}$

Clearly, it was becoming increasingly apparent that bestowing a compulsory status on Agriculture and other vocational courses was in itself no guarantee that the public would readily embrace these branches of instruction. Instead, the public often concluded that such compulsory practical instruction actually 
disadvantaged many youth by removing the element of curriculum and subject choice. ${ }^{125}$ Parr, it seems, had not learned that New Zealanders were not kindly disposed to the introduction of courses - especially compulsory ones - that they perceived unfavourably.

Little progress in the direction of popularising rural education courses was made by any of Parr's successors. The Syllabus Revision (Lawson) Committee appointed in 1926 by Robert Wright, Minister of Education in the Coates government (1925-1928), seemingly was oblivious to both published and oral accounts of rural communities' social, economic, and educational expectations when it reported in 1928 that equality of educational opportunity could simply be achieved by 'more effective educational guidance with a distinct bias to rural life'.126 Similarly, the Parliamentary Recess Education (Atmore) Committee in 1930 declared that there were tangible benefits to be gained from post-primary school based agricultural courses. Clearly influenced by Atmore's personal view that 'all types of schools shall play their part as effectively as possible in counteracting the undoubtedly dangerous drift of population from the country to the towns', 127 the Committee later reported that:

It has been abundantly demonstrated by the evidence taken that it [the subject of agriculture] has not had that pride of place, that emphasis, or that practical application which it ought to have. Except, therefore, in a few isolated schools and districts...the teaching of agriculture in our schools may be said so far to have been not very successful. ${ }^{128}$

\section{TOWARDS A GENERAL EDUCATION CURRICULUM: 1930-1945}

What the Recess Education Committee had identified was the reality that while academic and commercial instruction had retained its popular appeal in the district high schools over the years, agricultural and other rural-related courses had fared poorly. Furthermore, there was ample statistical evidence to support such a conclusion: between 1915 and 1920, an average of 38.3 per cent of New Zealand district high school pupils studied Latin, 36.6 per cent studied French, and 63.4 per cent chose Chemistry and Physics. For the same period, some 30 per cent of district high school pupils on average were studying two or more commercial subjects. ${ }^{129}$ Given that all of these subjects were available in the public examination syllabuses, they were assured of a prominent place in the post-primary school curriculum. These subjects were further supported by an employment market which was expanding steadily in the professional, public administration, commercial and financial sectors. ${ }^{130}$ On average, 61 per cent of male district high school pupils studied Agricultural Science over the period 19151920,131 but much of the reason for this apparent popularity of agriculture was that a compulsory status had been assigned to it in 1917 by the then Minister of Education, Josiah Hanan. 132

Notwithstanding the fact that 76 per cent of all male pupils attending district high schools in New Zealand were receiving Agricultural Science instruction by $1930, \mathbf{1 3 3}$ there still were frequent complaints about the dominance of academic instruction at these institutions and the poor status accorded publicly to agricultural studies. ${ }^{134}$ The prevailing 'social efficiency' thesis - that students of 
varying intellectual ability benefited from being placed in different schools and courses - continued to be trumpeted throughout the 1930s by Directors and Ministers of Education. Theo Strong, Director of Education (1927-1933), for example, was totally committed to a selective schooling policy which sought to persuade boys attending rural high schools to undertake the full agriculture course. ${ }^{135}$ That such a course should have won official support is all the more remarkable because New Zealand had been experiencing a significant downturn in international demand for its agricultural products since 1921, as a result of the onset of the severe worldwide economic depression.136 Taking up this theme, James Strachan, Principal of Rangiora High School, summed up the views of many rural educators when he informed the Atmore Committee that:

It seems to be fashionable at the moment to hold some pronounced views on the subject of agricultural education....As far as can be gathered from current opinion, agricultural education is being put forward as a remedy, or at least a palliative, for some of the economic ills that afflict us. ${ }^{137}$

Strachan and other commentators were understandably keen to ensure that rural youth would in no way be disadvantaged in competing for jobs with their urban counterparts. Any arguments advanced in favour of a selective schooling policy - i.e. where the curriculum provided to individual pupils was to be determined in accordance with the type of post-primary school they attended, their intended length of stay, and future employment options $\mathbf{1 3 8}^{\mathbf{1 3 8}}$ - were received unsympathetically. Widespread public support for such a schooling policy was necessary if it was ever to be introduced successfully. In the absence of such support, an increasingly comprehensive (multi-lateral) post-primary schooling system began slowly to emerge in New Zealand; a development that originated with the founding of the district high schools in the mid 1850s. Any official suggestion of introducing a rural bias into the district high schools' curricula was likely to meet with continuing resistance. Commenting on the problems associated with rural courses of instruction at the international level, L.E. Matthael, Chief of the Agricultural Service for the International Labour Office of the League of Nations, declared that:

Rural bias, if it means keeping the population on the land, is really a sentimental end pursued in defiance of a fundamental law in economics. Countryside education should never be such that the town and country children can be said to have been differently educated. Rural bias would be an injustice to the rural population by putting them at a disadvantage on seeking employment.... The boys and girls in the country must have the privilege of the same education as those in the towns. ${ }^{139}$

Matthael's sophisticated understanding of the complexities of rural life worldwide was sharply at odds with Harry Atmore, Minister of Education (19281931) and his successor, Robert Masters (19931-1934), both of whom left the educational community in no doubt that they favoured having agriculture 
included compulsorily in all school courses and examinations. ${ }^{140}$ By this date, however, even the traditionally loyal and conservative inspectorate was beginning to question the wisdom of pushing low-status agricultural instruction upon an unsympathetic public.

With the election of the first Labour government in December 1935 came a new political climate which gave an added impetus to the reconsideration of priorities in the education system in general and in post-primary schooling in particular. The Labour party had campaigned on a platform of promoting equality of educational opportunity through a non-selective schooling policy, ${ }^{142}$ and this was reiterated by Peter Fraser, Minister of Education, in 1939 when he asserted that:

The Government's objective, broadly expressed, is that every person, whatever his level of academic ability, whether he be rich or poor, whether he live in town or country, has a right, as a citizen, to a free education of the kind for which he is best fitted, and to the fullest extent of his powers.... If there is to be true equality of opportunity, by one method or another the country child must be given access to the facilities from which he has always tended to be barred by the mere accident of location....143

Fraser's determination 'to give the country child the same educational advantages as are enjoyed by those who reside in the cities', ${ }^{144}$ however, did not mean that he was about to abandon school-based agricultural instruction altogether. ${ }^{145}$ Rather, he noted that,

To say that the [Labour] government is determined that the country child shall have as good an education as the town child is not to say that he shall invariably have exactly the same in every detail. ${ }^{\mathbf{1 4 6}}$

Fraser's successor, Rex Mason, continued with the same policy into the 1940s. Mason's shrewd observation that 'traditionally, rural New Zealand demands all the advantages that fall to the lot of the city child', 147 revealed his appreciation of the low public regard for agricultural instruction and the high status assigned to academic, examination-oriented courses. ${ }^{148}$ Accordingly, Mason was unwilling to intervene legislatively to disturb the educational aspirations of rural New Zealanders, and instead sought to reassure rural communities that 'the policy in the future will be to make still greater efforts to give the country child educational opportunities equal to those of the city child'. ${ }^{149}$ No longer would rural folk and their children be treated as second-class citizens. ${ }^{150}$ To this end, Mason had taken into account the observations of James Mcllraith, the Chief Inspector of Primary Schools, who in 1937 had reported that,

Though the [district high school] pupils are mainly drawn from rural districts, it cannot be assumed that either they or their parents intend that the pupils' future vocation will be associated with rural life. In fact, a considerable percentage of these pupils are in attendance for the express purpose of qualifying for city vocations. ${ }^{151}$ 
Mason, like Fraser, was sympathetic to the idea of continuing with agricultural subjects in the district high schools. 152 Nevertheless, he and his Departmental officials were aware of the growing debate, both local and international, about the merits of introducing a general education curriculum into the post-primary schools. 153 Such a curriculum had the potential to minimise, if not eliminate, curricular biases and to allow pupils to choose from a range of optional studies those subjects most closely related to their future vocational destinations. The Thomas Committee, set up in November 1942 by Mason and Beeby (the Director of Education), recorded its support for such a curriculum philosophy. ${ }^{154}$ Mason specifically charged the Thomas Committee with the seemingly impossible task of persuading parents, employers, teachers, and pupils of the need to no longer regard public school examinations - particularly Matriculation - as being the only measure of a worthwhile education programme. The compulsory common core curriculum provisions outlined by the Committee in their report published in 1944, and the provision of a wide range of subjects in the Department's own soon-to-be revamped School Certificate Examination, Mason predicted, would ensure that all high school pupils would receive a 'generous and well balanced education'.155 Significantly, in its anxiety to reinforce the place of general (non-vocational) education subjects, the Thomas Committee recommended abolishing compulsory agricultural instruction in the district high schools, ${ }^{156}$ secure in the knowledge that '[earlier] attempts to persuade rural parents to enter their children for courses specifically fitting them for life on the land...had not been successful'.157 The Committee's recommendations were translated into practice in 1946.158

Many district high school teachers welcomed the new curriculum philosophy and predicted that the lower status assigned to these institutions by the public would disappear once agricultural instruction was made optional. William McIlroy of Palmerston District High School, for example, observed that prior to the introduction of the Thomas Committee's curriculum proposals,

That section of the public which is much interested in secondary education seems to regard them [district high schools] as third best, the poor relation of other secondary schools...the pupils often feel inferior in social position and in educational opportunity to those in other postprimary schools. ${ }^{159}$

From the outset, Beeby's influence was very evident in the Thomas Committee's deliberations. 160 Being firmly of the view that compulsory agricultural instruction could never be a solution to the rural-urban drift phenomenon viewed so negatively by some spokespeople, he concluded that 'the remedy lay not within the educational system as much as the social system' ${ }^{161}$ Despite overwhelming evidence to the contrary, there still were politicians - conservative and liberal who insisted that a rural curriculum bias in district high schools would automatically solve every economic ill in New Zealand.162

From the rural communities' point of view, the central importance of academic course offerings in their high schools was not to be underestimated. The existence of such courses, many commentators argued, served to deflect 
criticism that the district high schools were 'the wart on the nose of the [postprimary] education system' due to their Cinderella-type status. ${ }^{163}$ No government which valued rural electoral opinion was prepared to block access to academic courses, despite the fact that very few district high school leavers ever embarked upon university study. ${ }^{164}$ As Thom has noted, parents of district high school pupils were keen to ensure that their children were 'acquiring something that will be acceptable in the commercial world'.165 Success in high-status public school examinations, the Director of Education, T.B. Strong observed in 1933, had long been equated with the opportunity to enter higher status, better remunerated, white-collar urban employment. Strong summarised the position thus:

[Some farmers] insisted on their boys, who were eventually going to be farmers, studying such subjects as Latin and French to the neglect of [other] subjects...the desire of parents that their children should secure a pass in the University Matriculation Examination, even though there was no prospect of their going to the university, also accounted to some extent for the avoidance of the practical agricultural course. 166

There is ample evidence that Strong's observations were equally valid in the 1940s and beyond.

\section{THE CLOSING YEARS: 1946-1969}

The Thomas Committee's recommendations subsequently were embodied in the Education (Post-Primary Instruction) Regulations gazetted on 26 September 1945 and issued to all post-primary schools at the end of 1945 . These regulations not only set out the new post-primary school curriculum - i.e. the nature and scope of the 'common core' subjects - but also specified the conditions governing the award of the School Certificate Examination. ${ }^{\mathbf{1 6 7}}$ Added to these was the passage of the Education (School Age) Regulations which raised the school leaving age from 14 to 15 years as of February 1944, thereby making compulsory universal post-primary schooling an accomplished fact. 168 The combined effect of these regulations was an immediate - at times, almost unmanageable - increase in both post-primary entry numbers and pupil retention rates. In short, unprecedented numbers of pupils embarked upon post-primary schooling after 1943 and having gained entry, tended to remain longer at school.169

The vastly changed composition of the post-primary schools from 1944 taxed the resources of the Department of Education to such an extent that by the late 1950s there were unprecedented school accommodation problems and shortages in the supply of qualified teachers. ${ }^{170}$ While it was true that few post-primary schools escaped these difficulties, the district high schools were particularly illequipped to deliver the newly-introduced core curriculum requirements (particularly in art, music, and social studies). ${ }^{171}$ Furthermore, with a staff of two or three, the district high schools were able to offer only a narrow range of subject options for the fifth form School Certificate Examination, and very few district high schools prepared pupils for the sixth form University Entrance Examination. With this in mind, the Department in 1944 introduced boarding allowances (to an 
annual value of $£ 40$ ) for those district high school pupils who had passed the School Certificate Examination and who wished to attend an urban secondary school in order to prepare for the University Entrance Examination. 172 Despite the existence of such allowances, critics continued to complain that in practice many rural pupils still were prevented from moving to form six classes in the town secondary schools owing to the heavy expense involved.173

The anomalous position of the district high schools was further confirmed by the fact that most were absent from the list of schools that were eligible to accredit students for the University Entrance Examination. When the details of accrediting were released in 1943, the Canterbury Education Board complained that the University of New Zealand's refusal to grant to the district high schools the right to accredit would result in a drift of pupils to the town secondary schools, thereby diminishing further the status of the rural high schools. ${ }^{174}$ The Canterbury Board's fear was endorsed by the Otago Education Board which argued that parents needed to feel reassured that their children, whether they lived in the town or country, were given the same opportunities and privileges under the accrediting system. ${ }^{175}$ The Department of Education, however, did not appear to share these concerns: it argued that because the University Entrance Examination was intended to be taken 'only by those going to the University', pupils wanting this qualification would in any case be compelled to travel to the city to study at one of the university colleges. ${ }^{176}$ Pupils who wanted to obtain an examination qualification for general employment purposes only were thus expected to enter for the lesser School Certificate Examination. In this way, the Department was able to argue that district high schools would now be freed from the need to provide for specialist instruction in the sixth form, and would be able to do 'full justice to the work of their pupils up to the School Certificate stage'.177 Although the NZEI throughout the years 1944-1946 renewed its plea for the district high schools to be allowed to accredit, only six of the 97 district high schools were placed on the accrediting list. ${ }^{178}$

Other problems confronted the district high schools. The pace of urbanisation was beginning to have a noticeable impact upon rural life, and despite the inclusion of agriculture in the School Certificate Examination, Leonard Wild's 1958 survey indicated that only 17 of the 104 district high schools continued to teach agriculture. ${ }^{179}$ Two reasons can be offered to explain the decline in the popularity of agriculture: first, most rural parents preferred their children to take the 'general' course at school and, if they should so decide, a more specialised course later; and, second, agricultural courses were not recognised for employment as was the case for those school courses that led on to trades apprenticeships.

Faced with the reality of declining enrolments and a diminishing share of the total post-primary school population - 8.4 per cent in 1960 compared with 18.0 per cent in $1945^{180}$ - a number of district high schools had merged with neighbouring secondary schools or consolidated into secondary schools proper by the early 1960s. Identifying rural education as being one of six 'areas of concern', the Currie Commission in 1962 commented at length on the place of the district high schools in the overall education structure and noted that these schools lacked not only 'sufficient staff to give a wide range of specialised teaching' but also 'enough pupils to provide economically a wide range of courses'.181 Concluding 
that the secondary departments of the district high schools, as presently organised, 'do not go near enough to the ideal of providing full educational equality for country children', the Commissioners recommended that separate Form 1-6 (later, Form 7) schools be formed whenever the number of pupils in an area where consolidation was viable exceeded 180.182 The educational benefits of such a move included an increase in the number and diversity of staff, the provision of a wider range of courses (the Commission specifically recommended that agriculture not be introduced as a University Entrance subject), and more equipment for specialist instruction. 183

In 1962 the first Form 1-6 school was established, and over the next eight years another 23 such schools and one 'area' school (formed by combining the two senior classes from all the primary schools in an area with the secondary department of an existing district high school) - Maniototo, at Ranfurly - were opened. ${ }^{184}$ By 1980, the district high schools had all but disappeared. As Roy Nash has noted, the introduction of a unified pay scale for area school teachers and a more appropriate level of funding (i.e. a higher per capita grant than other secondary schools), have undoubtedly done much to ease the reorganisation of district high schools into Form 1-6 and area schools. ${ }^{185}$ That said, however, many smaller rural high schools continue to experience difficulties in staffing some specialist areas - in particular, mathematics, science, and technology - and consequently are forced to rely on the Correspondence School to provide such instruction. ${ }^{186}$ Today the rural high schools' viability is further threatened by constraints such as remoteness, travel time, and insufficient funding for professional development, all of which effectively diminish the capacity of rural school staff to implement the recent curriculum (New Zealand Curriculum Framework) and assessment (National Qualification Framework) reforms. ${ }^{187}$

In reviewing the century-old district high school movement, one can hardly claim that education policy makers' assaults on the academic curriculum were even remotely successful. Instead, the historical picture that emerges is one in which generations of educationists, politicians, and visiting experts - indeed, it seems, everyone except those who either taught in the district high schools or utilised the schools' services - viewed the rural schools' offerings as somehow dysfunctional because they chose to focus upon high-status, academic, examinable subjects rather than low-status, practical, non-examinable ones. The mistaken assumption here - and it was one that was widespread - was that the demand of ambitious rural youth for access to competitive school credentials was radical rather than conservative.

The history of the district high schools clearly indicates that it was not. In fact, the stock complaint raised was that studying agricultural subjects actually placed rural youth at a considerable disadvantage in terms of their ability to compete in examinations alongside their urban counterparts who faced no such requirement. Moreover, many rural folk claimed that they could provide their children with the necessary rural expertise and that they sent their children to school for the express purpose of being taught those subjects about which they knew very little. Looked at in this way, 'academic' education was often regarded as a means by which to escape the rigours and limitations of farming life. Against this expectation, the reformist sentiments of New Zealand educationists and politicians were of little avail. The lesson to be learned from studying the 
historical development of New Zealand district high schools is that education systems are powerless tools of social policy when the problems to be tackled lie outside the educational domain.

\section{NOTES AND REFERENCES}

1. A.G. Butchers, The Education System, Auckland: National Printing Co. Ltd. 1932, pp.33, 42; A.E. Campbell, Educating New Zealand, Wellington: Department of Internal Affairs, 1941, p.44; J. Mackey, The Making of a State Education System: The Passing of the New Zealand Education Act, 1877, London: Geoffrey Chapman, 1967, pp.91-130, 136.

2. J.D.S. McKenzie, 'Local Authority and Educational Development: A study of the Otago Education Board from 1877 to 1899', PhD thesis, University of Otago, Dunedin, 1973, p.3.

3. Ibid.

4. A.H. Thom, The District High Schools of New Zealand, Wellington: NZCER, 1950, p.2.

5. Ibid., pp.3-5.

6. Ibid., pp.4-6; J. Devaliant, Lawrence District High and Consolidated Schools Centennial History: 1864-1964, Dunedin: Otago Daily Times and Witness Newspapers Co. Ltd., 1964, pp.11-12.

7. Devaliant (1964), p.12.

8. Thom (1950), pp.1-16.

9. Ibid., p.8; Devaliant (1964), p.20; O. Duff, New Zealand Now, Wellington: Department of Internal Affairs, 1941, pp.96-99.

10. Thom (1950), p.8.

11. G.D. Lee, 'From Rhetoric to Reality: A History of the Development of the Common Core Curriculum in New Zealand Post-Primary Schools', PhD thesis, University of Otago, Dunedin, 1991, pp.5-8, 12-13.

12. The Education Act, 1877, Sections 54, 73. New Zealand Statutes (1877), pp.121122.

13. Ibid, Section 54 .

14. Ibid., Section 56.

15. D. McKenzie, 'The Growth of School Credentialling in New Zealand: 18781900 ', in R. Openshaw and D. McKenzie (Eds.), Reinterpreting the Educational Past, Wellington: NZCER, 1987, p.98.

16. The Education Reserves Act, 1877, Section 2.

17. AJHR (1902), E-1B, pp.94-95 (Report of the Otago Education Board); (1909), E-1, pp.40-41; E-6, p.9; (1910), E-2, p.144 (Report of the Otago Education Board Inspectors, P. Goyen, C.R. Richardson, C.R. Bossence, J.R. Don); Otago Daily Times, 23 July 1909; 25 June 1910 (Conference of Members of the North Canterbury Education Board, Masters of District High Schools, and Head Assistants of Secondary Departments); 23 June 1911; Evening Star, 11 July 1911.

18. Thom (1950), pp.9, 13.

19. AJHR (1884), E-1, p.67.

20. Thom (1950), p.9. 
21. I.A. McLaren, 'Education and Politics: Background to the Secondary Schools Act, 1903 Part 1: Secondary Education for the Privileged', NZJES, 1970, vol.5, no.2, pp.94-95.

22. AJHR (1879), H-1, pp.316-319; Thom (1950), p.11.

23. Ibid., (1901), E-1c, p.3; Otago Daily Times , 18 October 1901.

24. New Zealand Journal of Education (1910), vol.12, no.120 (April), p.54.

25. G. Lee and H. Lee, Examinations and the New Zealand School Curriculum: Past and Present, Palmerston North: Delta Research Monograph No.12, 1992, p.2.

26. Otago Daily Times, 18 October 1901; AJHR (1904), I-14B, p.26; Auckland Weekly News (1 December 1904); New Zealand Times (15 September 1905); Thom (1950), pp.13, 21.

27. NZPD (1885), Vol.52, p.115 (Stout: 21 July); Otago Daily Times, 20 February 1891, 20 October 1899, 23 July 1909, 23 June 1911; AJHR (1906), E-1B, p.26 (Report of the Wellington Education Board Inspectors, T.R. Fleming, F.H. Bakewell); (1910), E-2, p.144 (Report of the Otago Education Board Inspectors, P. Goyen, C.R. Richardson, C.R. Bossence, J.R. Don); (1914), E-6, pp.23-24 (Report of Wellington Inspectors on District High Schools), E-5, p.33 (Report of Taranaki Inspectors on District High Schools).

28. AJHR (1901), E-1c, p.3 (Report of the 1901 Conference of Inspectors); Otago Daily Times, 18 October 1901.

29. 'District High School Regulations', 8 January 1901. AJHR (1901), E-1, p.109, Clauses 5 and 7.

30. Ibid., Clause 6.

31. Ibid., Clause 5.

32. Ibid., Clauses 5 and 7.

33. Ibid., Clause 1.

34. Ibid., Clause 9.

35. Ibid., Clause 5.

36. AJHR (1901), E-1c, p.3; Evening Star, 10 May 1902.

37. Ibid. (authors' emphasis).

38. R. Openshaw, G. Lee and H. Lee, Challenging the Myths: Rethinking New Zealand's Education History, Palmerston North: Dunmore Press, 1993, pp.96119.

39. AJHR (1904), E-14, p.12; (1905), E-12, p.5; (1906), E-12, p.5.

40. Ibid (1902), E-1, p.xvi (authors' emphasis). Hogben's decision to address the Farmers' Union meeting came about, ironically, through illness. In May 1904, he had a complete break down and spent his sick leave (although not fully recovered, he returned to work in October) at Napier with his friend Henry Hill, the Hawke's Bay Inspector of Schools. Not content to spend his time in convalescence, Hogben took the opportunity to inspect many of the local schools and to deliver his lecture on agricultural education (see Herbert Roth, George Hogben: A Biography, Wellington: NZCER, 1952, p.122).

41. Ibid.

42. Ibid. (1904), I-14B, p.24.

43. Ibid., p.26.

44. Ibid., p.25.

45. Ibid. (1904), E-14 (Education: Some Aspects of Education in New Zealand).

46. Ibid., p.12. 
47. Ibid.

48. H. Lee, in R. Openshaw and D. McKenzie, op cit., pp.111-121. See also H. Lee, 'The Junior Civil Service Examination Reconsidered: A Study of the Changing Function of a Competitive Examination, 1900-1912', History of Education Review, 1987, Vol.16, No.2, pp.57-66.

49. J.E. Shramka, 'Petone School and its Teachers: 1882-1918', MA thesis, Victoria University of Wellington, 1985.

50. Ibid., p.123.

51. Ibid., p.124.

52. Ibid., p.125. The Hutt and Petone Chronicle, 20 June 1911.

53. Ibid., pp.124-125. The Hutt and Petone Chronicle, 11 February 1911.

54. Ibid., p.126.

55. Ibid.

56. AJHR (1906), E-1B, p.45.

57. Ibid., p.23. Kay Matthews, in 'The Long and Winding Road: The Role of the Nineteenth Century School Inspector: A Case Study' (in R. Openshaw and D. McKenzie, op. cit., pp.147-158), provides an interesting portrait of the life and educational experiences of Inspector Henry Hill.

58. Ibid. (authors' emphasis).

59. Ibid. (1907), E-1E, p.7.

60. Ibid.

61. Ibid. (1911), E-6, p.12; Thom (1950), p.28.

62. J.E. Watson, 'Agricultural Education in Post-Primary Schools', MA thesis, University of Otago, 1949, p.20.

63. Ibid. Thom (1950), pp.28-30.

64. Thom (1950), pp.41-45.

65. G. Lee and H. Lee (1992), pp.31-35.

66. AJHR (1909), E-6, p.9; (1910), E-6, p.12.

67. Ibid. (1911), E-1, p.35.

68. Otago Daily Times, 23 July 1909, article entitled 'Extending Technical Education, outlining the Education Department's memorandum dated 22 July 1909'; 4 August 1910, article entitled 'Educational Syllabus - Nature Study and Agricultural Science'.

69. Ibid. (20 March 1908).

70. Ibid. Chief Inspector Peter Goyen's address to the Otago Education Board meeting entitled 'Extending Technical Education - Important Departmental Proposals'.

71. Ibid. Refer also to Otago Daily Times, 26 May 1910, article entitled 'District High Schools - Suggested Rural Course'; Evening Star, 11 July 1910, article entitled 'Agricultural Instruction in District High Schools'.

72. Ibid.

73. AJHR (1907), E-1E, p.3; (1910), E-10, pp.18, 38.

74. Ibid. (1910), E-10, p.7.

75. Ibid. (1901), E-1c, p.3; E-12, pp.6-7; (1910), E-10, p.28; Openshaw, Lee and Lee (1993), pp.103-4, 109-111.

76. Ibid. (1910), E-10, p.24.

77. Circular Memorandum to Secretaries of Education Boards, 8 January 1901. AJHR (1901), E-1, p.109; 'The Free Place Regulations - December 1902', in 
I.A. McLaren, 'Secondary Schools in the New Zealand Social Order: 18401903 ', PhD thesis, Victoria University of Wellington, 1965, Appendix (v); 'Regulations Respecting Free Places in Secondary Schools and District High Schools, 30 October 1905, 27 February 1906', New Zealand Gazette (1905), Vol. 4, pp. 2523-2526 (30 October 1905); 'Amended regulations under the Education Act, 1908, and its Amendments, as to the Organisation, Inspection, and Examination of Public Schools, and the Syllabuses of Instruction', New Zealand Gazette (1913), Vol.4, pp.3681-3703 (15 December 1913); 'Regulations regarding Free Places in Secondary Schools and District High Schools', New Zealand Gazette (1917), Vol. 2, pp. $2769-2773$ (9 July 1917); 'Amended Regulations relating to Free Places and Certificates of Secondary Instruction', New Zealand Gazette (1926), Vol. 3, pp. 3121-3122 (1 November 1926); 'Education Act 1914 - Amended Regulations', New Zealand Gazette (1929), Vol. 3, pp. 2647-2654 (14 October 1929); 'Regulations under the Education Act, 1914 - Amended Regulations', New Zealand Gazette (1929), Vol.3, pp.2654-2658 (14 October 1929); New Zealand University Calendars, 1900-1940.

78. AJHR (1910), E-10, pp.3, 16-25.

79. Letters from Miss M.E.A. Marchant, Principal, Otago Girls' High School, to J.R. Sinclair, Chairman, Otago High Schools' Board of Governors, 3 February 1906, 18 September 1907, 30 July 1908; Letter from W.J. Morrell, Rector, Otago Boys' High School, to J.R. Sinclair, 13 February 1908. Otago High Schools' Board, Files and Correspondence, 1906-1908; New Zealand Schoolmaster, March 1907, p. 121; AJHR (1911), E-6, p.12.

80. AJHR (1910), E-6, p.11; Otago Daily Times, 19 December 1910.

81. Ibid. (1912), E-12, p.37.

82. Ibid., p.44.

83. Ibid., pp.57-58 (Evidence of E.K. Mulgan), p.487 (Evidence of G.D. Braik).

84. Ibid., p.521.

85. Ibid.

86. Ibid., p.370. See also pp.115, 117, 430, 433, 519, 736.

87. Ibid.

88. Ibid., p.725. See also pp.115-116.

89. New Zealand Journal of Education (1912), vol.14, no.146, p.210 (October).

90. AJHR (1912), E-12, pp.15-16 (authors' emphasis).

91. Ibid.

92. Ibid. (1918), E-6, p.21; (1919), E-6, p.14; (1920), E-6, pp.4, 13; (1921-2922), E-6, p.5; (1926), E-5, p.6.

93. Ibid. (1915), E-6, p.10.

94. I. and A. Cumming, 'Thirty Formative Years in New Zealand Education: The Perspective of a Colonial Headmaster', NZJES, 1981, Vol. 16, No. 1, pp.70-77; I. and A. Cumming, 'Foundation Years of the Auckland Girls' Grammar School', NZJES, 1971, Vol. 6, No. 2, pp. 108-110; AJHR (1912), E-12, p. 141 (Evidence of C.E. Bevan-Brown), p. 388 (Evidence of J.W. Caughley), pp. 44, 417, 711 (Evidence of C.E. Bevan-Brown), p. 320 (Evidence of T.D. Pearce); A.R. Dunlop and A.E. Dakin (Eds.), Southland Boys' High School Old Boys' Register: 1881-1956, Invercargill, Southland High School Old Boys' Association, 1958, p. 11-12. 
95. This recognition of the short-stay phenomenon was incorporated directly into the Free Place Regulations which set out in detail subjects of instruction for free-place form three and four boys and girls. New Zealand Gazette (NZG) (1908), Vol. 2, pp. 1109-1111; Evening Star, 14 December 1911.

96. AJHR (1916), E-1A, p.1. Evening Star, 18 May 1916 (Hanan's address to the New Zealand Secondary Schools' Annual Conference). Hanan was Minister of Education in the National Ministry from 12 August 1915 to 23 August 1919.

97. Ibid.

98. New Zealand Journal of Education (NZJE), June 1912, p. 105; October 1912, pp. 208-210; Otago Daily Times, 21 April 1911, 12 December 1913, 23 August 1918, 22 August 1919; Evening Star, 26 October 1915, 6 July 1918; Evening Post, 8 July 1916; New Zealand Parliamentary Debates (NZPD) (1917), Vol. 180, pp. 372-373; 1917, Vol. 178, p. 878; AJHR (1920), E-5, p.9.

99. Otago Daily Times, 21 April 1911, 19 May 1911; NZJE, October 1912, pp. 208210; AJHR (1914), E-6, pp. 22-23; (1915), E-5, p.10; (1915), E-6, p. 10; (1916), E-6, p. 19; (1917), E-6, pp. 13, 18; (1918), E-5, p. 27; (1918), E-6, pp. 15-16.

100. AJHR (1916), E-1A, pp. 4-6; Otago Daily Times, 6 March 1917. The 'continuation course' was to prepare school leavers for work in the trades and industries while the 'country secondary course' was to devote special attention to agriculture (NZPD, 1917, Vol. 180, p. 527; Evening Star, 31 August 1918).

101. Ibid., pp. 1-3, 7, 11; NZPD (1917), Vol. 180, p. 52.

102. Ibid., pp. 1, 11; (1917), E-1, pp. 42, 49; (1917), E-6, p.4.

103. Ibid. (1916), E-1A, pp. 1-11; (1917), E-1, pp. 3-4, 9, 42-44, 49; New Zealand Gazette (1917), Vol. 2, pp. 2769-2773; NZPD (1916), Vol. 175, p. 115; (1917), Vol. 180, pp. 526-527.

104. New Zealand Gazette (1917), Vol. 2, pp. 2769-2773 (Regulations regarding Free Places in Secondary Schools and District High Schools, 9 July 1917). Technical High School 'junior' free-place pupils were obliged also to study History and civics and Home Science. See NZG (1917), Vol. 2, pp. 3029-3034 (Regulations dated 13 July 1917). The subjects of Practical Agriculture and Dairy Science were compulsory for 'junior' boys at district high schools where there were fewer than 70 pupils in the secondary departments. Refer to NZG (1917), Vol.2, p. 2770, Clause 6.

105. New Zealand Gazette (1917), Vol. 2, pp. 2769-2773 (Regulations regarding Free Places in Secondary Schools and District High Schools, 9 July 1917).

106. J.D.S. McKenzie, 'Why Practical Education Doesn't Work: The Demise of the New Zealand Technical Schools', University of Otago Open Lecture, Dunedin, 23 July 1986, pp. 10-12; J.D.S. McKenzie, 'The New Zealand Labour Party and Technical Education: 1919-1930', Paper presented to ANZHES Annual Conference, Hobart, August 1987, pp. 4-6.

107. Education Department Circular Memorandum No. 1917/25, 13 July 1917; NZPD (1917), Vol. 180, pp. 532-533; New Zealand Gazette (1917), Vol. 2, pp. 2447-2448.

108. New Zealand Gazette (1917), Vol. 2, pp. 2769-2773; 3029-3034; J.D.S. McKenzie, 'Politics and School Curricula', in W.J.D. Minogue (Ed.), Adventures in Curriculum, Sydney: George Allen and Unwin, 1983, p.27. 
109. AJHR (1919), E-6, p.16. See also AJHR (1912), E-12, pp. 115, 117 (1914), E-6, p. 24 (1916), E-6, p. 18 (1919), E-6, p. 14; New Zealand Journal of Education (1912), vol. 14, no. 146, pp. 208-210 (October). 'Pennib', a columnist for the New Zealand Journal of Education in 1912, was especially alert to the consequences of promoting vocational subjects such as agriculture in school curricula. He wrote: 'Undoubtedly, to do more of one [subject] we must do less of the other. Of what shall we do less? Each subject has its advocates, hence the difficulty of elimination or of curtailment'. Ibid. (1912), vol. 14, no. 142, p. 105 (June).

110. AJHR (1919), E-6, pp. 15-16.

111. Ibid. (1912), E-12, pp. 361, 365-366.

112. Ibid. See also Otago Daily Times, 15 June 1912; AJHR (1912), E-12, pp. 108, $130,222,272,320,555,557$.

113. Openshaw, Lee and Lee (1993), pp. 113-115, 117-119.

114. AJHR (1912), E-12, pp. 222, 237, 241, 306, 373, 388, 720.

115. AJHR (1912), E-1, p. 38; Otago Daily Times, 19 September 1913; Report of the Otago Education Board (1913), p. 30; NZPD (1917), Vol. 180, p. 525; (1924), Vol. 204, p. 418; (1925), Vol. 206, p. 756; National Education, 1 September 1922, p. 287; A.H. Thom, op. cit., pp. 22-36; L.J. Wild, The Development of Agricultural Education in New Zealand, Christchurch: Whitcombe and Tombs Ltd., 1953, pp. 9-11.

116. F. Tak, Investigations into Certain Aspects of Post-Primary Education in New Zealand (Tate Report), Special Report on Educational Subjects No. 16, Wellington: Government Printer, 1925, p.1.

117. Ibid.

118. Ibid., pp. 40, 50 .

119. $A J H R$ (1924), E-1, p.7.

120. NZPD (1924), Vol. 204, p. 418; (1924), Vol. 205, p. 987 (M. Cohen); (1925), Vol. 206, p. 764 (R. Hudson); (1925), Vol. 206, pp. 766-767 (R. Masters); (1925), Vol. 208, p. 590 (F. Langstone); (1926), Vol. 209, p. 948 (A. Samuel); (1928), Vol. 219, pp. 139, 142 (H. Armstrong and W. Martin); (1930), Vol. 224, pp. 351-353 (H. Atmore), pp. 364, 372, 377, 388 (W. Lysnar, W. Bodkin, T. McDonald and G. Black), p. 382 (J. Young); Education Gazette (1 August 1930), p. 152.

121. AJHR (1923), E-2, p. xix.

122. Ibid. (1922), E-2, p. xviii; (1923), E-2, p. xvi; (1924), E-2, pp. xxix-xxx; (1925), E-2, p. 65; Report of the Otago Education Board (1924), p. 32; (1925), p. 32; (1926), p. 32; (1929), p. 37; (1930), p. 21.

123. Ibid. (1923), E-2, p. ii; E-5, p.3; (1924), E-1, p. 25; E-5, p.8; (1925), E-5, p.6; (1927),

124. Education Gazette (1 July 1925), p. 108 (authors' emphasis).

125. Ibid. (1 April 1933), p. 51; STA, June 1936, p. 13; 1 September 1936, p. 286.

126. Report of the Syllabus Revision Committee 1926-1928 (Lawson Report), Wellington: Government Printer, 1928, p. 60.

127. AJHR (1929), E-1, p.3.

128. Report of the Parliamentary Recess Education Committee on Educational Reorganisation in New Zealand (Atmore Report), Wellington: Government Printer, 1930, p. 32. Published in AJHR (1930), I-8A. 
129. AJHR (1916-1921), E-6, Table L2. See also AJHR (1918), E-6, p. 4; G. Lee (1991), p. 167.

130. G. Lee (1991), p. 168; Report of the Education Board of the District of Otago, Dunedin: Coulls Somerville Wilkie, 1929, pp. 37-38; (1930), p. 21.

131. AJHR (1916-1921), E-6, Table L2; G. Lee (1991), p. 167.

132. Evening Star, 25 September 1916; 31 August 1918; NZPD (1917), vol. 178, p. 878; New Zealand Gazette (1917), vol. 2, pp. 2769-2773; Otago Daily Times , 22 August 1919.

133. AJHR (1930), E-6, Table L2.

134. Ibid. (1919), E-6, p. 4.

135. Education Gazette (1 April 1933), p. 51; The Sun, 28 February 1933; NZPD (1933), vol. 235, p. 1235; (1933), vol. 236, pp. 38-39.

136. AJHR (1931), E-6, p. 4.

137. Education Gazette (1 March 1930), p. 40; NZPD (1930), vol. 224, p. 389.

138. Lee and Lee (1992), pp. 9-11; Openshaw, Lee and Lee (1993), pp. 132-161.

139. National Education (1 September 1930), pp. 425-427.

140. AJHR (1930), I-8A, pp. 29, 32, 120, 146-147; (1932), E-2, p. 25; Otago Daily Times, 16 July 1930, 4 October 1933 ('District High Schools: Development of Work - A more practical course'), NZPD (1930), Vol. 224, pp. 353, 372; National Education, 1 September 1930, p. 424; 1 November 1935, p. 484; 2 March 1936, p. 54; Education Gazette (1 August 1932), pp. 124-125.

141. AJHR (1929), E-6, pp. 3-4 (Report of E.J. Parr); (1932), E-2, pp. 5-6 (Report of E.J. Parr); (1933), E-2, p. 6 (Report of E.J. Parr); (1935), E-2, p. 2 (Report of Dr J. McIlraith); (1936), E-2, pp. 10 (Report of E.J. Parr), 16 (Report of W. La Trobe).

142. Lee and Lee (1992), pp. 12-14; Openshaw, Lee and Lee (1993), p. 161; NZPD (1936), vol. 245, p. 534.

143. $A J H R$ (1939), E-1, pp. 2-3.

144. Ibid. (1936), E-1, p. 3; (1937), E-1, p. 3; (1937-1938), E-1, p. 3; NZPD (1939), vol. 255, p. 483.

145. Ibid. (1938), E-1, p.4.

146. Ibid. (1939), E-1, pp. 6, 12.

147. H.G.R. Mason, Education Today and Tomorrow, Wellington: Government Printer, 1945, p. 48.

148. Ibid., pp. 48-49; AJHR (1941-1942), E-1, p. 2; (1944), E-1, p. 2; (1945), E-2, p. 4.

149. Mason (1945), p. 51; AJHR (1941-1942), E-1, p. 2; (1945), E-1, p.3.

150. NZPD (1934), vol. 238, p. 548; (1936), vol. 245, p. 534.

151. AJHR (1937-1938), E-2, p. 5; (1939), E-2, p. 4.

152. Mason (1945), p. 52; AJHR (1946), E-1, p.9.

153. AJHR (1934-1935), E-2, p. 6; (1937-1938), E-2, p. 8; (1941), E-2, p. 7; A.E. Campbell (Ed), Modern Trends in Education: The Proceedings of the New Education Fellowship Conference held in New Zealand in July 1937, Wellington: Whitcombe and Tombs, 1937, pp. 287, 321, 411; J.E. Strachan, New Zealand Observer: A Schoolmaster Looks at America, New York: Columbia University Press, 1940, pp. 22, 27-29, 38-39; G. Lee (1991), pp. 498-669; Openshaw, Lee and Lee (1993), pp. 162-176. 
154. The Post-Primary School Curriculum. Report of the Committee appointed by the Minister of Education in November 1942 (Thomas Report), Wellington: Government Printer, 1944 (reprinted 1959), pp. 1, 5-8, 12-13.

155. Ibid, p. 5; AJHR (1943), E-1, p. 2; E-2, p. 2.

156. Thomas Report (1944, 1959), pp. 10, 12-17, 55, 60-61.

157. AJHR (1945), E-2, p. 4; Mason (1945), p. 49.

158. Department of Education, The Education (Post-Primary Instruction) Regulations, 1945, also Syllabuses of Instruction and School Certificate Examination Prescriptions, Wellington, Government Printer, 1945. Serial No. 1945/143 (gazetted on 26 September 1945. See New Zealand Gazette, 1945, Vol. 3, p. 1198).

159. National Education (1 August 1944), p. 213.

160. Openshaw, Lee and Lee (1993), pp. 169-170.

161. Otago Daily Times, 23 April 1945.

162. Education Gazette (1 April 1933), p. 51; (1 May 1943), pp. 91-92; NZPD (1933), vol. 235, p. 1235; (1933), vol. 236, pp. 38-9; (1943), vol. 262, pp. 993-994; (1943), vol. 263, pp. 237, 310; (1944), vol. 264, p. 201; (1945), vol. 270, p. 322; National Education (1 November 1935), p. 484; (1 December 1944), pp. 357361; AJHR (1939), E-2, p. 13.

163. National Education (1 June 1943), p. 115; (1 March 1944), p. 71; (2 October 1944), p. 287; (3 April 1945), p. 79; (3 September 1945), pp. 214-215, 242; NZPD (1945), vol. 270, p.319; Otago Daily Times , 18 May 1939.

164. Education Gazette (2 October 1933), p. 164; AJHR (1934-1935), E-1, p. 3; (1938), E-2, p.19; National Education (1 June 1934), p. 202; (1 June 1936), pp. 234-235; (1 August 1936), p. 337; (7 May 1937), p. 136; Otago Daily Times , 31 November 1939, 13 December 1939.

165. Thom (1950), p. 86.

166. Education Gazette (1 April 1933), p. 51. See also AJHR (1932), E-2, p. 6; (1933), E-2, p. 6; (1935), E-2, p.3.

167. The Education (Post-Primary Instruction) Regulations, 1945, pp. 2-3, Clauses 2 and 7(4). See also Education Gazette (1945), vol. 24, no. 11, pp. 280-282 (November).

168. Education Gazette (1944), vol. 23, no. 2, p. 39 (February); vol. 23, no. 4, p. 76 (April).

169. Between 1944 and 1954, the post-primary school rolls increased from 40382 to 66089 (63.7 per cent); the fifth form rolls from 10925 to 17238 (57.8 per cent), and the sixth form rolls from 2602 to 5730 (120.2 per cent). Data from AJHR $(1945,1955)$, E-1, Tables E.1 and I.2; E-2.

170. C. Whitehead, 'The Thomas Report - A Study in Educational Reform', NZJES, vol. 9, no. 1, May 1974, pp. 57-59; I.A. McLaren, Education in a Small Democracy: New Zealand, London: Routledge and Kegan Paul, 1974, p. 104.

171. Thom (1950), pp. 72-80.

172. AJHR (1945), E-1, p. 3.

173. National Education (3 September 1945), p. 215. Letter to the Editor from D.M. Jillet, Ohakune District High School.

174. Otago Daily Times, 18 November 1943.

175. Ibid., 17 February 1944.

176. Ibid. 
177. Ibid.

178. National Education (1 March 1944), p. 72; (1 April 1944), p. 104; (1 December 1944), p. 374; (3 April 1945), pp. 73, 79-80; (1 April 1946), p. 100.

179. L.J. Wild, Consultative Committee on Agricultural Education, Wellington: Government Printer, 1958.

180. Report of the Commission on Education in New Zealand (Currie Report), Wellington: Government Printer, 1962, p. 170, Table 3.

181. Ibid., pp. 161, 444.

182. Ibid., pp. 444, 446.

183. Ibid., pp. $445,456$.

184. J.C. Dakin, Education in New Zealand, Auckland: Leonard Fullerton, 1973, p. 69; McLaren (1974), p. 68; R. Nash, 'The New Zealand District High Schools: A Case Study in the Selective Function of Rural Education', NZJES, vol. 16, no. 2, November 1981, p. 157.

185. Nash (1981), pp. 157-158.

186. 'Rural Funding Facts', Education Gazette (16 October 1995).

187. Dominion Sunday Times , 14 November 1993; Eduvac (15 November 1993, 18 November 1996); Otago Daily Times (17 April 1993, 8 September 1993, 8 October 1993, 9 October 1993, 16 October 1993, 3 June 1995, 12 February 1996, 12 April 1996, 1 May 1996, 2 May 1996, 27 July 1996). 